\title{
PERLINDUNGAN HUKUM TERHADAP BANK ATAS PERJANJIAN KREDIT KONSUMSI BAGI ORANG ASING
}

\author{
Rachmadani Eka Husnul Khotimah, Thohir Luth, Hanif Nur Widhiyanti \\ Magister Kenotariatan Universitas Brawijaya \\ Jalan Veteran, Malang, Jawa Timur \\ Email : rekahk27@gmail.com
}

\begin{abstract}
Since 2005 the rule of Bank Indonesia is already issued a policy about consumer credit facilities in order to get a place or a home for foreign people who live in Indonesia, but it is not enough to make all the bank that took place in Indonesia give that facilities. One of the reasons discrepancy of a number banks to give that credit facilities to foreign people is because the risk in case there is a failure or the person is not fulfilling the obligation. Considering the debtor is a foreigner, while the object of the guarantee is a land with a right of use that has a limited period, and until now there is still no regulations from both the Indonesian government and from Bank Indonesia that specifically provide protection against banks on consumer credit facilities for foreigners. In this paper, the writer will discuss the effort of legal protection that can be done by the Bank are preventive effort and repressive effort. Preventive legal protection efforts undertaken by banks is with credit agreements. Repressive legal protection effort, if the foreign debtors can not fulfill the obligation one of them is to stop the consumer credit agreement.
\end{abstract}

\section{Keywords : Protection, Bank, Foreign people, Use Right, Credit Consumption Agreement}

\begin{abstract}
Abstrak
Peraturan Bank Indonesia sejak tahun 2005 sudah mengeluarkan kebijakan fasilitas kredit konsumsi untuk dapat memiliki rumah tempat tinggal atau hunian orang asing yang berkedudukan di Indonesia, namun tidak cukup membuat semua bank yang ada di Indonesia memberikan fasilitas tersebut. Kesenjangan jumlah perbankan untuk memberikan fasilitas kredit kepada orang asing salah satunya disebabkan oleh faktor resiko jika terjadi kegagalan atau wanprestasi. Mengingat debitur adalah orang asing, sementara objek jaminan adalah tanah dengan hak pakai yang mempunyai jangka waktu terbatas, dan sampai saat ini masih belum ada regulasi baik dari pemerintah Indonesia maupun dari Bank Indonesia yang secara spesifik memberikan perlindungan terhadap Bank atas fasilitas kredit konsumsi bagi orang asing. Dalam tulisan ini, penulis akan membahas mengenai upaya perlindungan hukum yang dapat dilakukan oleh Bank yakni upaya preventif dan upaya represif. Upaya perlindungan hukum preventif yang dilakukan oleh bank adalah dengan perjanjian kredit dan Upaya perlindungan hukum represif, bila mana debitur orang asing tersebut wanprestasi salah satunya adalah menghentikan perjanjian kredit konsumsi.
\end{abstract}

Kata Kunci : Perlindungan, Bank, Orang Asing, Hak Pakai, Perjanjian Kredit Konsumsi

\section{A. Pendahuluan}


Tanah mempunyai fungsi dan kedudukan yang sangat sentral dan bersifat strategis di dalam berbagai aspek kehidupan politik, ekonomi, sosial budaya, hukum, ekologi dan pertahanan keamanan. Dalam aspek ekonomi, tanah dapat memberikan kesejahteraan berupa pendapatan melalui transaksi jual beli, sewa menyewa, jaminan Hak Tanggungan dan sebagainya. Dengan karakteristik tanah yang unik, karena persediaan tanah selalu tetap, artinya tidak dapat diproduksi, tetapi dalam beberapa kondisi dapat berkurang, dan lokasinya tidak dapat digeser atau dipindahkan.

Ketentuan yuridis yang mengatur mengenai segala sesuatu tentang tanah dan sampai sekarang masih berlaku yaitu dalam Undang-Undang Nomor 5 Tahun 1960 tentang Peraturan Dasar Pokok Pokok Agraria, Lembaran Negara Tahun 1960 Nomor 104, Tambahan Lembaran Negara Nomor 2043 (selanjutnya disebut dengan UUPA).

Dalam UUPA juga dikenal adanya hak menguasai tanah oleh negara yang di atur dalam Pasal 2 ayat (1) UUPA menyatakan bahwa, "Atas dasar ketentuan dalam Pasal 33 ayat 3 Undang-Undang Dasar 1945 dan hal-hal sebagai yang dimaksud dalam Pasal 1, bumi air dan ruang angkasa, termasuk kekayaan alam yang terkandung di dalamnya itu pada tingkatan tertinggi dikuasai oleh negara, sebagai organisasi kekuasaan seluruh rakyat".

Wewenang negara yang bersumber pada hak untuk menguasai dan mengatur tanah oleh negara yang diatur dalam Pasal 4 UUPA. Wewenang untuk menggunakan tanah tersebut baru ada setelah tanah itu dibuka. Jadi hak disini maksudnya adalah hak yang memberi wewenang kepada pemegang haknya untuk menggunakan tanahnya Pasal 4 ayat (2) UUPA. ${ }^{2}$

Menurut Pasal 4 ayat (1), atas dasar hak menguasai tanah oleh negara, negara berwenang untuk menentukan macam-macam hak atas tanah diatur terdapat dalam Pasal 16 UUPA. $^{3}$

Menurut Pasal 16 ayat (1) UUPA, hak-hak atas tanah dapat dibagi menjadi 3 macam, yaitu: ${ }^{4}$

1. hak-hak atas tanah yang bersifat tetap yaitu: hak milik, hak guna usaha, hak guna bangunan, hak pakaiidan hak sewa;

2. hak-hak atas tanah yang bersifat sementara yang disebut dalam Pasal 53 yaitu : hak gadai, hak usaha bagi-hasil, hak menumpang dan ihak sewa tanah pertanian;

3. hak-hak atas tanahi yang akan ditetapkan dengan undang-undang.

Konsep hak atas tanah secara umum telah dijelaskan pada pemaparan diatas, sedangkan konsep hak atas tanah yang digunakan dalam penulisan hukum ini adalah hak pakai. Hak Pakai itu sendiri diatur dalam Pasal 41 - 43 UUPA. Dirincikan dalam Peraturan Pemerintah

\footnotetext{
${ }^{1}$ Muhammad Bakri, Hak Menguasai Tanah oleh Negara (Paradigma Baru untuk Reformasi Agraria), (Malang: Universitas Brawijaya Press, 2011). hlm. 21-22.

2 ibid., hlm. 39.

${ }^{3}$ Sebagaimana tercantum dalam Pasal 16 UUPA

${ }^{4}$ Muhammad Bakri,Op.Cit., hlm. 40.
} 
No. 40 Tahun 1996 tentang Hak Guna Usaha, Hak Guna Bangunan dan Hak Pakai atas Tanah, Lembaran Negara Tahun 1996 Nomor 59, Tambahan Lembaran Negara Nomor 3643 (selanjutnya disebut PP No. 40 Tahun 1996).

Pengertian Hak Pakai di atur dalam Pasal 41 UUPA berbunyi: "Hak Pakai adalah hak untuk menggunakan dan/atau memungut hasil dari tanah yang dikuasai langsung oleh negara atau tanah milik orang lain, yang memberi wewenang dan kewajiban yang ditentukan dalam keputusan pemberiannya oleh pejabat yang berwenang memberikannya atau dalam perjanjian dengan pemilik tanahnya yang bukan perjanjian sewa-menyewa atau perjanjian pengolahan tanah, segala sesuatu asal tidak bertentangan dengan jiwa dan ketentuan-ketentuan undangundang." 5

Sebagaimana diatur dalam Pasal 42 UUPA yang dapat memiliki atau menggunakan hak pakai adalah (Pasal 39 PP No. 40 Tahun 1996) antara lain :6

1. Warga Negara Indonesia;

2. Badan hukum yang didirikan menurut hukum Indonesia dan berkedudukan di Indonesia yang sudah disahkan menurut Undang-undang;

3. Departemen, Lembaga Pemerintahan Non Departemen, dan Pemerintah Daerah yang masih aktif;

4. Badan-badan keagamaan dan sosial yang masih aktif;

5. Orang asing yang berkedudukan di Indonesia dan mempunyai izin tinggal di Indonesia;

6. Badan hukum asing yang mempunyai perwakilan di Indonesia dan mempunyai izin di Indonesia;

7. Perwakilan negara asing dan perwakilan badan Internasional yang sudah diatur dalam Undang-Undang.

Salah satu peralihan hak pakai bisa dilakukan dengan jual beli yang penulis akan gunakan yaitu jual beli dengan perjanjian kredit oleh bank. Menurut Pasal 1 ayat (11) Undang-Undang Nomor 10 Tahun 1998 tentang perubahan atas Undang-Undang Nomor 7 Tahun 1992 tentang Perbankan, Lembaran Negara Republik Indonesia Tahun 1992 Nomor 31, Tambahan Lembaran Negara Republik Indonesia Nomor 3472 sebagaimana telah diubah dengan Undang-Undang Nomor 10 Tahun 1998, Lembaran Negara Republik Indonesia Tahun 1998 Nomor 182, Tambahan Lembaran Negara Republik Indonesia Nomor 3790 (selanjutnya disebut UU Perbankan) berbunyi : "Kredit adalah penyediaan uang atau tagihan yang dapat dipersamakan dengan itu, berdasarkan persetujuan atau kesepakatan pinjam

\footnotetext{
${ }^{5}$ Pasal 41 Undang-Undang Nomor 5 Tahun 1960 tentang Peraturan Dasar Pokok-pokok Agararia, Lembaran Negara Tahun 1960 Nomor 104, Tambahan Lembaran Negara Nomor 2043.

${ }^{6}$ Supardi Marbun, Bahan Ajar Diklat Dasar Pertanahan Tingkat II Hak Atas Tanah, (Jakarta: Pusdiklat Kementerian ATR/BPN, 2015), hlm. 42-43.
} 
meminjam antara Bank dengan pihak lain yang mewajibkan pihak peminjam untuk melunasi utangnya setelah jangka waktu tertentu dengan pemberian bunga." 7

Kemudian yang dimaksud dengan perjanjian kredit adalah perjanjian pemberian kredit antara pemberi kredit dan penerima kredit wajib di tuangkan dalam bentuk perjanjian kredit. Jenis-jenis kredit berdasarkan tujuannya itu sendiri di bagi menjadi tiga yaitu sebagai berikut .8

1. Kredit Produktif digunakan untuk peningkatan bidang usaha atau produksi atau investasi. Kredit ini diberikan oleh bank untuk menghasilkan barang atau jasa. Sebagai contoh, kredit diberikan untuk membangun sebuah pabrik. Kredit pertanian akan menghasilkan produk-produk pertanian. Kredit pertambangan akan menghasilkan bahan tambang atau bahan baku. Kredit industri akan menghasilkan produk industri kebutuhan masyarakat pada umumnya;

2. Kredit Perdagangan untuk keperluan membeli komoditas atau barang yang akan didagangkan atau dijual kembali. Pembayaran uang diharapkan dari hasil penjualan barang dagangan tersebut. Kredit ini diberikan kepada suplier atau agen-agen perdagangan yang membeli produk atau barang dalam jumlah relatif besar. Contoh kredit ekspor impor untuk perdagangan yang melakukan transaksi ekspor impor;

3. Kredit Konsumsi, adalah pemberian kredit atau pembiayaan untuk keperluan konsumsi di dalam negeri dengan cara membeli, menyewa atau dengan cara lain, termasuk di dalamnya Kredit atau pembiayaan Pemilikan Rumah, Apartemen, Ruko, dan Rukan serta kredit pembelian kendaraan.

Kemudahan dalam pemberian pelayanan maupun izin memperoleh hak atas tanah untuk rumah tempat tinggal atau hunian bagi orang asing yang bisa di ajukan dengan dapat melalui cara kredit oleh bank. Bank juga harus mengantisipasi dalam memberikan kredit, bank selalu memakai prinsip $5 \mathrm{C}$, yaitu The Five Principles of Credit Analysis, yang menghendaki penelitian seksama mengenai watak dan kemampuan berusaha debitur, modal apa yang sudah dimilikinya, jaminan apa yang dapat diberikan dan keadaan perekonomian Negara pada umumnya yang sekiranya dapat mendukung usaha debitur.

Bank sebagai lembaga Pembiayaan yang bersifat mencari keuntungan dengan itu maka bank Indonesia mengeluarkan aturan mengenai pemberian kredit bagi WNA yang termuat di dalam Peraturan Bank Indonesia No. 7/14/PBI/2005 tentang Pembatasan Transaksi Rupiah dan pemberian kredit valuta asing oleh bank, aturan ini dicabut dan digantikan dengan Peraturan Bank Indonesia No. 18/19/PBI/2016 tentang Transaksi Valuta Asing Terhadap Rupiah antara Bank dengan Pihak Asing, Lembaran Negara Republik Indonesia Tahun 2016 Nomor 184, Tambahan Lembaran Negara Republik Indonesia Nomor 5927 (selanjutnya di

\footnotetext{
${ }^{7}$ Pasal 1 ayat (11) Undang-Undang Nomor 10 Tahun 1998 tentang Perubahan Atas Undang-Undang Nomor 7 Tahun 1992 tentang Perbankan, Lembaran Negara Republik Indonesia Tahun 1998 Nomor 182, Tambahan Lembaran Negara Republik Indonesia Nomor 3790.

${ }^{8}$ https://ardra.biz/ekonomi/ekonomi-perbankan-lembaga-keuangan/jenis-jenis-kredit-bank/ . diakses 16 Januari 2018.
} 
sebut PBI No: 18/19/PBI/2016). Adapun larangan transaksi bank dengan orang asing yang di atur dalam Pasal 15 PBI No. 18/19/PBI/2016 adalah sebagai berikut: ${ }^{9}$

1. Pemberian Kredit atau pembiayaan dalam rupiah dan/atau valuta asing;

2. Penempatan dalam rupiah;

3. Pembelian Surat Berharga dalam rupiah yang diterbitkan oleh Pihak Asing;

4. Tagihan Antar Kantor dalam rupiah;

5. Tagihan Antar Kantor dalam valuta asing dalam rangka pemberian Kredit atau pembiayaan di luar negeri;

6. Penyertaan Modal dalam rupiah.

Dari larangan tersebut PBI No. 18/19/PBI/2016 juga mengatur pengecualian terhadap pelarangan transaksi yang di atur dalam Pasal 15 huruf a yang berbunyi: ${ }^{10}$

1. Kredit atau Pembiayaan non tunai atau garansi yang terkait dengan kegiatan investasi di Indonesia yang memenuhi persyaratan berikut:

a. memperoleh counter guaranty (kontra garansi) dari Prime Bank yang bukan merupakan:

1) kantor cabang Bank di luar negeri; dan

2) kantor cabang bank yang berada di dalam maupun di luar negeri; atau

b. adanya jaminan setoran sebesar $100 \%$ (seratus persen) dari nilai garansi yang diberikan.

2. Kredit atau Pembiayaan dalam bentuk sindikasi yang memenuhi persyaratan berikut:

a. mengikutsertakan Prime Bank sebagai lead bank yang memenuhi persyaratan sebagai berikut:

1) memiliki peringkat investasi yang diberikan oleh lembaga pemeringkat paling kurang :

a) BBB- dari lembaga pemeringkat Standard \& Poors;

b) Baa3 dari lembaga pemeringkat Moody's;

c) BBB- dari lembaga pemeringkat Fitch; atau

d) Setara dengan angka i, angka ii, dan/atau angka iii berdasarkan penilaian lembaga pemeringkat terkemuka lain yang ditetapkan oleh Bank Indonesia;

berdasarkan penilaian terhadap prospek usaha jangka panjang (long term outlook) Bank tersebut; dan

2) memiliki total aset yang termasuk dalam 200 (dua ratus) besar dunia berdasarkan informasi yang tercantum dalam Banker's Almanac.

\footnotetext{
${ }^{9}$ Pasal 15 Peraturan Bank Indonesia No. 18/19/PBI/2016 tentang Transaksi Valuta Asing Terhadap Rupiah antara Bank dengan Pihak Asing, Lembaran Negara Republik Indonesia Tahun 2016 Nomor 184, Tambahan Lembaran Negara Republik Indonesia Nomor 5927.

${ }^{10}$ Pasal 16 Peraturan Bank Indonesia No. 18/19/PBI/2016 tentang Transaksi Valuta Asing Terhadap Rupiah antara Bank dengan Pihak Asing, Lembaran Negara Republik Indonesia Tahun 2016 Nomor 184, Tambahan Lembaran Negara Republik Indonesia Nomor 5927.
} 
b. diberikan untuk pembiayaan proyek di sektor riil untuk usaha produktif yang berada di wilayah Indonesia; dan

c. kontribusi bank asing sebagai anggota sindikasi lebih besar dibandingkan dengan kontribusi Bank di dalam negeri.

3. Kartu kredit;

4. Kredit atau Pembiayaan konsumsi yang digunakan di dalam negeri;

5. Cerukan intrahari dalam Rupiah atau valuta asing yang didukung oleh dokumen yang bersifat authenticated yang menunjukkan konfirmasi akan adanya dana masuk ke rekening bersangkutan pada hari yang sama dan memenuhi persyaratan yang ditetapkan dalam Surat Edaran Bank Indonesia;

6. Cerukan dalam Rupiah atau valuta asing karena pembebanan biaya administrasi; dan

7. Pengambilalihan tagihan dari badan yang ditunjuk pemerintah untuk mengelola aset Bank dalam rangka restrukturisasi perbankan Indonesia oleh Pihak Asing yang pembayarannya dijamin oleh Prime Bank.

Secara Normatif WNA diperbolehkan memiliki hak atas tanah untuk rumah tempat tinggal atau hunian dengan cara kredit di bank, namun tidak cukup membuat semua bank yang ada di Indonesia memberikan fasilitas tersebut. Kesenjangan jumlah perbankan untuk memberikan fasilitas kredit kepada WNA salah satunya disebabkan oleh faktor resiko jika terjadi kegagalan atau wanprestasi dan perbankan masih bingung soal hak pakai dengan hak guna bangunan bagaimana cara pengalihan agunan tersebut, jika WNA tidak menetap dalam jangka waktu setahun, apakah WNA itu harus melepaskan kepemilikannnya? Lalu bagaimana proses peralihannya? Berapa lama prosesnya dan berapa biayanya?. ${ }^{11}$

Kepala Divisi Bisnis Kredit Konsumer PT Bank Central Asia Tbk (BCA) Felicia Mathelda Simon mengatakan, masih terlalu dini bagi perseroan untuk melakukan kerja sama dengan developer terkait pengadaan properti bagi WNA. Sebagai penyalur kredit, bank perlu memahami sisi legal status hak kepemilikan WNA maupun perjanjian kredit yang dapat dilakukan ke depan. Direktur Konsumer PT Bank Negara Indonesia (Persero) Tbk (BNI) Anggoro Eko Cahyo juga menegaskan, bank sebetulnya tidak anti menggarap kredit perumahan bagi WNA. "Sebaliknya, kami lebih ke arah bersama-sama memastikan regulasi yang ada supaya aman," jelas dia. Direktur Keuangan dan Treasury PT Bank Tabungan Negara (Persero) Tbk (BTN) Iman Nugroho Soeko menegaskan, perseroan belum berminat menggarap hal tersebut dalam jangka pendek karena bank pemerintah memang fokus di rumah pertama bagi kalangan menengah ke bawah. Sementara itu, SVP Consumer Loan Group PT Bank Mandiri (Persero) Tbk Harry Gale dan Head of Retail Banking Product PT Bank CIMB Niaga Tbk Budiman Tanjung menilai, kebijakan yang membuat WNA dapat memiliki hunian di Indonesia akan menjadi peluang meningkatkan pertumbuhan KPR secara industri ke depan. Namun Bank Mandiri akan terus mengikuti aturan main yang lebih jelas dari pemerintah terkait pengadaan KPR bagi WNA. "Seraya secara paralel, kami tentu

${ }^{11}$ https:// kreditgogo. com/ artikel/ Informasi- Umum/ Wow- Asing- Bisa- Beli- Properti. html, diakses pada 19 Maret 2018. 
lakukan kajian di internal untuk model bisnis, yakni mulai dari proses akuisisi, underwriting, hingga collection," ungkap Harry kepada Investor Daily. ${ }^{12}$

Dalam Pasal 12A UU Perbankan menyebutkan bahwa, Bank umum dapat membeli barang agunan melalui pelelangan umum, ataupun di luar pelelangan berdasarkan penyerahan secara sukarela oleh pemilik agunan untuk menjual di luar lelang, dalam hal nasabah atau debitur tidak dapat memenuhi kewajibannya kepada bank. Namun demikian, agunan yang dibeli oleh bank tersebut tidak dapat dimiliki oleh bank. Bank harus mencairkan ataupun menjual agunan yang dibeli tersebut secepatnya, paling lambat dalam waktu satu tahun, namun tentu saja tidak mudah menjual barang jaminan hak tanggungan dalam hal ini sertifikat hak pakai dalam waktu satu tahun. Jika jaminan tersebut dijual secara obral, maka pada akhirnya pihak kreditur dalam hal ini bank akan mengalami kerugian. Pentingnya penelitian ini sebagai alasan penulis adalah kurangnya perlindungan hukum terhadap bank atas jaminan hak tanggungan berupa hak pakai.

\section{B. Pembahasan}

Bank dalam memberikan kredit kepada pengusaha/ nasabah wajib mempunyai keyakinan atas kemampuan dan kesanggupan debitur untuk melunasi utangnya sesuai dengan yang diperjanjikan karena kredit yang diberikan oleh bank mengandung risiko, sehingga dalam pelaksanaannya bank harus memperhatikan asas perkreditan yang sehat dan asas kehati-hatian. Untuk mengurangi risiko jaminan pemberian kredit dalam arti keyakinan atas kemampuan dan kesangupan debitur untuk melunasi utangnya merupakan faktor penting yang harus diperhatikan oleh bank, dan untuk memperoleh keyakinan tersebut sebelum memberikan kredit, bank harus melakukan penelitian yang sesama terhadap watak, kemampuan, modal dan agunan serta prospek usaha debitur, yang dalam usaha perbankan dikenal dengan sebutan $5 \mathrm{C}$.

Jelaslah bahwa agunan merupakan salah satu syarat pemberian kredit, jadi apabila syarat 5C terpenuhi maka diperoleh keyakinan atas kemampuan debitur, dan kepada debitur yang bersangkutan akan diberikan kredit. Pemberian kredit merupakan kegiatan utama bank yang mengandung resiko yang dapat berpengaruh terhadap kesehatan dan kelangsungan usaha bank.

Namun mengingat sebagai lembaga intermediasi, sebagian besar dana bank berasal dari dana masyarakat, maka pemberian kredit perbankan banyak dibatasi oleh ketentuan undangundang, dan ketentuan bank Indonesia. Beberapa regulasi dimaksud antara lain adalah regulasi mengenai pelaksanaan kebijaksanaan perkreditan bank bagi bank umum, batas maksimal pemberian kredit, pemberian kredit terkait dengan ketentuan pembinaan dan pengawasan bank, dan pembatasan lainnya dalam pemberian kredit.

12 http:// www.beritasatu.com/bank-dan-pembiayaan/ 361530- soal- properti- bagi-wna- bank- tunggubeleid-pelaksanaan.html, diakses pada 19 Maret 2018. 
Bank Indonesia mengeluarkan aturan PBI No. 18/19/PBI/2016 tentang Transaksi Valuta Asing Terhadap Rupiah antara Bank Dengan Pihak Asing yang mengatur mengenai orang asing dapat memiliki hak atas tanah untuk rumah tempat tinggal atau hunian dengan cara kredit di bank, yang mana diatur dalam Pasal 15 dan Pasal 16. Maka dengan itu bank harus melindungi dirinya dari kebijakan tersebut dengan melalui perjanjian kredit yang dibuat. Dalam hal perjanjian kredit bank dapat melakukan asas kebebasan berkontrak yang mana tidak bertentangan dengan Undang-Undang, ketertiban umum dan kesusilaan, juga terpenuhinya syarat sahnya perjanjian. ${ }^{13}$

Sarana perlindungan hukum ada dua bentuk, yaitu sarana perlindungan hukum preventif dan sarana perlindungan hukum represif. Perlindungan hukum preventif yang dilakukan oleh bank adalah dengan perjanjian kredit. perjanjian kredit yang dibuat oleh bank untuk WNA tentu saja berbeda dengan perjanjian kredit untuk WNI, alasan perbedaan tersebut ada pada objek dan subjeknya. Untuk WNI subjek perjanjian kredit tersebut antara lain kreditur dan debitur, dan objeknya hak atas tanah berupa hak milik, hak guna usaha, hak guna bangunan dan semua hak yang tercantum di dalam Pasal 16 UUPA, berbeda dengan WNA subjek perjanjian kredit antara lain kreditur, debitur dan penjamin, sedangkan "objeknya hanya berupa hak atas tanah hak pakai". ${ }^{14}$

Tindakan perlindungan hukum yang bersifat represif dibagi menjadi dua cara yakni tindakan yang dituangkan didalam perjanjian kredit dan yang diluar perjanjian kredit, yang akan dijelaskan lebih lanjut adalah sebagai berikut :

1. Perlindungan Hukum Represif di Dalam Perjanjian Kredit, Represif yang dituangkan dalam perjanjian kredit, apabila Dalam hal terjadinya suatu kejadian pelanggaran atau wanprestasi berdasarkan perjanjian terjadi dan berlangsung maka bank berhak dan berwenang untuk: ${ }^{15}$

a. Menghentikan perjanjian kredit ini dengan mengesampingkan ketentuanketentuan pasal 1266 kitab undang-undang hukum perdata dan meyimpang pasalpasal yang lain;

b. Mengurangi batas jumlah fasilitas kredit yang dapat diberikan kepada debitur berdasarkan Perjanjian;

c. Bank menagih keseluruhan hutang dari debitur tanpa pemberitahuan surat peringatan ataupun somasi; dan

d. Bank langsung menjual harta benda yang dijaminkan oleh debitur kepada bank baik dibawah-tangan maupun dimuka umum atau secara lelang

\footnotetext{
${ }^{13}$ I Ketut Oka Setiawan, Hukum Perikatan, (Jakarta: Sinar Grafika, 2015), hlm. 69.

${ }^{14}$ Pasal 2 ayat (1) Peraturan Pemerintah Nomor 103 Tahun 2015 tentang Pemilikan Rumah Tempat Tinggal atau Hunian oleh Orang Asing yang Berkedudukan di Indonesia, Lembaran Negara Republik Indonesia Tahun 2015 Nomor 325, Tambahan Lembaran Negara Republik Indonesia Nomor 5793

${ }^{15}$ Perjanjian Kredit khusus WNA Bank Commonwealth, tbk.
} 
Dengan perlindungan hukum represif di dalam perjanjian kredit diatas, bank juga mempunyai perlindungan hukum reprensif di luar perjanjian kredit, agar bank dapat meminimalisir resiko-resiko, seperti resiko kredit, resiko likuiditas dan resiko lainnya.

2. Perlindungan Hukum Represif di Luar Perjanjian Kredit

Represif diluar perjanjian kredit konsumsi adalah dengan cara pengelolaan pinjaman (kredit) tertunggak, bank mempunyai tim yakni tim collection. Tim collection menerapkan strategi penagihan yang bertujuan untuk memelihara hubungan dengan nasabah untuk memperkecil kerugian yakni bentuk pendekatan pelayanan untuk penunggak awal dan pendekatan yang agresive untuk tunggakan selanjutnya. Tunggakan dilaporkan berdasarkan pada days past due secara bulanan. Days past due adalah umur tunggakan dari suatu account/produk berdasarkan pada jumlah hari (dalam hal tidak membayar) yang melampaui tanggal jatuh tempo pembayaran dengan klasifikasi kolektibilitas sebagai berikut (sesuai dengan ketentuan Regulator yang berlaku).

\begin{tabular}{|c|c|l|}
\hline $\begin{array}{c}\text { Umur } \\
\text { Tunggakan }\end{array}$ & Kolektibilitas & \multicolumn{1}{|c|}{ Keterangan } \\
\hline 0 & 1 & Lancar \\
\hline $1-90$ & 2 & Dalam Perhatian Khusus \\
\hline $91-120$ & 3 & Kurang Lancar \\
\hline $121-180$ & 4 & Diragukan \\
\hline$>180$ & 5 & Macet \\
\hline
\end{tabular}

Tindakan hukum yang bertujuan untuk memperoleh pelunasan hutang dengan jalan mengambil-alih/ menyita agunan atau asset debitur dapat dilakukan jika debitur tidak kooperatif dengan ketentuan sebagai berikut:

1. Telah terjadi wanprestasi, sebagaimana yang ditunjukkan dalam perjanjian kredit, yang dibuktikan dengan penerbitan 3 (tiga) kali surat peringatan;

2. Hasil perundingan tidak membuahkan hasil (Cash settlement atau Asset Settlement) hingga mencapai >180 DPD.

Dari pembahasan tersebut diatas maka penulis dapat memberikan jawaban bahwa perlindungan hukum terhadap bank atas perjanjian kredit konsumsi bagi Warga Negara Asing setelah dikeluarkannya kebijakan aturan PBI No. 18/19/PBI/2016 tentang Transaksi Valuta Asing Terhadap Rupiah antara Bank Dengan Pihak Asing melalui dua cara yakni perlindungan hukum preventif dan perlindungan hukum represif.

Perlindungan hukum preventif bank dapat melalui dengan perjanjian kredit sedangkan perlindungan hukum reprensif yang mana setelah terjadi kegagalan atau wanprestasi adalah dengan proses yang sudah ditentukan oleh masing-masing aturan 
bank baik di dalam perjanjian kredit maupun di luar perjanjian kredit dan diakhiri dengan lelang yang mana sudah diatur dalam UUHT. Namun UUHT masih belum mampu memberikan perlindungan terhadap bank selaku kreditur. Dikarenakan jaminan yang di gunakan adalah jaminan berupa hak pakai. Alasan belum mampunya hak pakai tersebut antara lain :

\section{Jangka Waktu Sementara}

Hak pakai itu sendiri mempunyai jangka waktu yang sudah diatur dalam Pasal 7, Pasal 8 dan Pasal 9 PMA No. 29 Tahun 2016, yang sudah dijelaskan secara detail di Bab II kajian umum tentang hak atas tanah bagi warga negara asing.

2. Kurang Diminati

Badan Kantor Pertanahan di Indonesia adalah tempat dimana semua yang berkaitan tentang tanah di Indonesia, baik itu perizinan dan pelepasan sertifikat tanah. Penulis menganalisa kurang diminatinya hak pakai dibandingkan dengan hak guna bangunan dapat dilihat dari adanya laporan Volume Penerbitan Sertifikat yang sudah terdaftar di BPN Kantor Cabang Jakarta Timur, Jalan Dr. Sumarno Pulogebang Jakarta Timur yakni : ${ }^{16}$

\begin{tabular}{|c|c|r|r|r|r|r|}
\hline No. & $\begin{array}{c}\text { Tahun } \\
\text { Terbit }\end{array}$ & $\begin{array}{c}\text { Hak Milik } \\
(\mathrm{HM})\end{array}$ & $\begin{array}{c}\text { Hak Guna } \\
\text { Bagunan } \\
(\text { HGB })\end{array}$ & $\begin{array}{c}\text { Hak } \\
\text { Pakai } \\
(\text { HP) }\end{array}$ & $\begin{array}{c}\text { Hak } \\
\text { Pengelolaan } \\
\text { (HPL) }\end{array}$ & $\begin{array}{c}\text { Hak } \\
\text { Wakaf } \\
(\mathrm{HW})\end{array}$ \\
\hline 1 & 2014 & 7,703 & 1,048 & 146 & 0 & 10 \\
\hline 2 & 2015 & 6,494 & 1,561 & 119 & 1 & 9 \\
\hline 3 & 2016 & 6,041 & 1,335 & 113 & 0 & 17 \\
\hline 4 & 2017 & 15,913 & 2,831 & 156 & 1 & 3 \\
\hline
\end{tabular}

3. Peningkatan Hak Pakai ke hak-hak atas tanah lainnya terlalu lama

Berikut syarat-syarat peningkatan serifikat hak pakai menjadi hak milik adalah sebagai berikut $:^{17}$

a. Untuk Tanah Luas dibawah $600 \mathrm{M}^{2}$ (apabila masa Haknya belum berakhir), Data yang wajib dlampirkan :

1. Sertipikat Asli Hak Pakai

2. IMB Fotocopy yang sudah dilegalisir

3. KRK dari Tata Ruang yang masa berlakunya tidak diatas 5 Tahun (apabila peruntukannya untuk Rumah Tinggal)

4. Foto Bangunan yang ada dilokasi

5. PBB Tahun Berjalan Fotocopy yang sudah dilegalisir

6. KTP Pemegang Hak Fotocopy yang sudah dilegalisir

\footnotetext{
${ }^{16}$ http://kkp.bpn.go.id/, (Diakses, 28 Februari 2018).

17 Ibid.
} 
7. Kartu Keluarga Fotocopy yang sudah dilegalisir

8. Mengisi Formulir Peningkatan Hak berdasarkan Wilayah setempat

9. Masa pengurusan sekitar 14 hari kerja

b. Untuk Tanah Luas diatas $600 \mathrm{M}^{2}$ (apabila masa Haknya sudah berakhir), Data yang wajib dlampirkan :

1. Sertipikat Asli Hak Pakai

2. IMB Fotocopy yang sudah dilegalisir

3. KRK dari Tata Ruang yang masa berlakunya tidak diatas 5 Tahun (apabila peruntukannya untuk Rumah Tinggal)

4. Foto Bangunan yang ada dilokasi

5. PBB Tahun Berjalan Fotocopy yang sudah dilegalisir

6. KTP Pemegang Hak Fotocopy yang sudah dilegalisir

7. Kartu Keluarga Fotocopy yang sudah dilegalisir

8. Mengisi Formulir Peningkatan Hak berdasarkan Wilayah setempat

9. Melakukan Pendaftaran Pengukuran untuk mengeluarkan Surat Ukur yang baru

10. Setelah Surat Ukur terbit mendaftarkan untuk Pembaharuan Hak untuk membuat SK baru

11. Masa pengurusan seperti membuat atau penerbitan Sertipikat Baru, prosesnya kira2 sekitar 4 - 6 bulan tergantung kebijakan Kantor Pertanahan setempat.

c. Untuk Tanah Luas diatas $600 \mathrm{M}^{2}$ sampai $2.000 \mathrm{M}^{2}$ (apabila masa Haknya belum berakhir), Data yang wajib dlampirkan :

1. Sertipikat Asli Hak Pakai

2. IMB Fotocopy yang sudah dilegalisir

3. KRK dari Tata Ruang yang masa berlakunya tidak diatas 5 Tahun

4. Foto Bangunan yang ada dilokasi

5. PBB Tahun Berjalan Fotocopy yang sudah dilegalisir

6. KTP Pemegang Hak Fotocopy yang sudah dilegalisir

7. Kartu Keluarga Fotocopy yang sudah dilegalisir

8. Mengisi Formulir Peningkatan Hak berdasarkan Wilayah setempat

9. Melakukan Pendaftaran Pengukuran untuk mengeluarkan Surat Ukur yang baru

10. Setelah Surat Ukur terbit mendaftarkan untuk Pembaharuan Hak untuk membuat SK baru

11. Masa pengurusan seperti membuat atau penerbitan Sertipikat Baru, prosesnya kira2 sekitar 4 - 6 bulan tergantung kebijakan Kantor Pertanahan setempat.

d. Untuk Tanah Luas diatas $600 \mathrm{M}^{2}$ sampai $2.000 \mathrm{M}^{2}$ (apabila masa Haknya sudah berakhir), Data yang wajib dlampirkan :

1. Sertipikat Asli Hak Pakai 
2. IMB Fotocopy yang sudah dilegalisir

3. KRK darai Tata Ruang yang masa berlakunya tidak diatas 5 Tahun (apabila peruntukannya untuk Rumah Tinggal)

4. Foto Bangunan yang ada dilokasi

5. PBB Tahun Berjalan Fotocopy yang sudah dilegalisir

6. KTP Pemegang Hak Fotocopy yang sudah dilegalisir

7. Kartu Keluarga Fotocopy yang sudah dilegalisir

8. Formulir Peningkatan Hak berdasarkan Wilayah setempat

9. Melakukan Pendaftaran Pengukuran untuk mengeluarkan Surat Ukur yang baru

10. Setelah Surat Ukur terbit mendaftarkan untuk Pembaharuan Hak untuk membuat SK baru

11. Masa pengurusan seperti membuat atau penerbitan Sertipikat Baru, prosesnya kira2 sekitar 4 - 6 bulan tergantung kebijakan Kantor Pertanahan setempat.

Namun semua syarat tersebut ada pengecualiannya antara lain $:^{18}$

a. Apabila dilokasi tidak ada bangunannya maka untuk proses peningkatannya tidak bisa diproses dan harus segera dibangun dahulu.

b. Bahwa Peruntukannnya harus Hunian, selain dari itu tidak bisa diproses karena melanggar dengan Peraturan yang ada.

\section{Penutup}

Berdasarkan hasil pembahasan diatas, maka dapat disimpulkan sebagai berikut:

1. Perlindungan hukum terhadap Bank atas Perjanjian Kredit Konsumsi bagi orang asing melalui dua sarana perlindungan hukum antara lain:

a. Perlindungan hukum prefentif yakni perlindungan hukum sebelum terjadinya wanprestasi, bank dapat melakukan perlindungan hukum dengan dibuatnya perjanjian kredit yang dituangkan dalam pasal-pasal, yang mengatur semaksimal mungkin hak dan kewajiban WNA dan kreditur agar lebih menjaminkan tidak terjadinya wanprestasi.

b. Perlindungan hukum refresif yakni perlindungan hukum setelah terjadi wanprestasi, yang dibagi dalam dua bentuk antara lain :

1) Perlindungan Hukum Refresif di dalam Perjanjian Kredit, disebutkan bahwa bank dapat melakukan perlindungan hukum sebagai berikut :

a. Menghentikan perjanjian kredit;

b. Mengurangi batas jumlah fasilitas kredit;

c. Bank menagih keseluruhan hutang dari debitur tanpa pemberitahuan surat peringatan; dan

\footnotetext{
${ }^{18}$ Ibid.
} 
d. Bank langsung menjual harta benda yang dijaminkan oleh debitur kepada bank baik dibawah-tangan maupun dimuka umum atau secara lelang.

2) Perlindungan Hukum Refresif di luar Perjanjian Kredit adalah dengan cara pengelolaan pinjaman (kredit) tertunggak, bank mempunyai tim yakni tim collection. Tim collection menerapkan strategi penagihan yang bertujuan untuk memelihara hubungan dengan nasabah untuk memperkecil kerugian yakni bentuk pendekatan pelayanan untuk penunggak awal dan pendekatan yang agresive untuk tunggakan selanjutnya.

2. Penulis mengharapkan dan menyarankan agar semua bank dapat memberikan fasilitas kredit konsumsi bagi WNA tanpa takut terjadi resiko-resiko yang timbul, karena dengan memberikan fasilitas tersebut bank dapat berkontribusi secara langsung dalam memajukan perekonomian Indonesia yang masih berkembang.

\section{DAFTAR PUSTAKA}

\section{Buku}

I Ketut Oka Setiawan, Hukum Perikatan. Jakarta: Sinar Grafika, 2015.

Muhammad Bakri, Hak Menguasai Tanah oleh Negara (Paradigma Baru untuk Reformasi Agraria). Malang: Universitas Brawijaya Press, 2011.

\section{Peraturan Perundang-undangan}

Undang-Undang Dasar 1945

Kitab Undang-Undang Hukum Perdata

Undang-Undang Nomor 5 Tahun 1960 tentang Peraturan Dasar Pokok Pokok Agraria Lembaran Negara Tahun 1960 Nomor 104, Tambahan Lembaran Negara Nomor 2043.

Undang-Undang No. 4 Tahun 1996 tentang Hak Tanggungan atas Tanah beserta BendaBenda yang berkaitan dengan Tanah Lembaran Negara Republik Indonesia Tahun 1996 Nomor 42, Tambahan Lembaran Negara Republik Indonesia Nomor 3632.

Undang-Undang Nomor 10 Tahun 1998 tentang Perubahan Atas Undang-Undang Nomor 7 Tahun 1992 tentang Perbankan Lembaran Negara Republik Indonesia Tahun 1998 Nomor 182, Tambahan Lembaran Negara Republik Indonesia Nomor 3790.

Peraturan Pemerintah No. 40 Tahun 1996 tentang Hak Guna Usaha, Hak Guna Bangunan dan Hak Pakai atas Tanah Lembaran Negara Tahun 1996 Nomor 59, Tambahan Lembaran Negara Nomor 3643.

Peraturan Pemerintah Nomor 103 Tahun 2015 tentang Pemilikan Rumah Tempat Tinggal atau Hunian oleh Orang Asing yang Berkedudukan di Indonesia Lembaran Negara Republik Indonesia Tahun 2015 Nomor 325, Tambahan Lembaran Negara Republik Indonesia Nomor 5793.

Peraturan Menteri Agraria dan Tata Ruang / Badan Pertanahan Nasional Nomor 29 Tahun 2016 tentang Tata Cara Pemberian, Pelepasan, atau Pengalihan Hak atas Pemilikan Rumah Tempat Tinggal atau Hunian Orang Asing yang berkedudukan di Indonesia Berita Negara Republik Indonesia Tahun 2016 Nomor 1442. 
Peraturan Bank Indonesia No. 18/19/PBI/2016 tentang Transaksi Valuta Asing Terhadap Rupiah antara Bank Dengan Pihak Asing, Lembaran Negara Republik Indonesia Tahun 2016 Nomor 184, Tambahan Lembaran Negara Republik Indonesia Nomor 5927.

\section{Naskah}

Perjanjian kredit khusus WNA Bank Commonwealt. Tbk.

Perjanjian Kredit WNI Bank Maybank. Tbk.

Syarat-syarat Peningkatan sertifikat hak pakai di Kantor BPN.

\section{Internet}

www.medanbisnisdaily.com/Bank Jangan Sembarangan Beri Kredit ke Warga Asing, kamis, 02 April 2016, diakses 8 Januari 2018.

https://ardra.biz/ekonomi/ekonomi-perbankan-lembaga-keuangan/jenis-jenis kredit-bank/ . diakses 16 Januari 2018.

http://kkp.bpn.go.id/, Diakses, 28 Februari 2018.

https:// kreditgogo. com/ artikel/ Informasi- Umum/ Wow- Asing- Bisa- Beli- Properti. html, diakses pada 19 Maret 2018.

http:// www.beritasatu.com/bank-dan-pembiayaan/ 361530- soal- properti- bagi-wna- banktunggu- beleid-pelaksanaan.html, diakses pada 19 Maret 2018. 